\title{
JUDICIAL INDEPENDENCE AT THE CROSSROADS: GRAPPLING WITH IDEOLOGY AND HISTORY IN THE NEW NEPALI CONSTITUTION
}

\author{
David Pimentel*
}

\section{INTRODUCTION}

Nepal is struggling to produce a new constitution, the blueprint for a new post-monarchic state. The political and ideological history of Nepal, including a checkered history with constitutionalism, complicates the picture, particularly as it applies to the structure of the new Nepali judiciary. The rhetoric of the various parties seems similar in terms of what each envisions in the new constitution, but the conflicts beneath the rhetoric loom large. While there appears to be consensus among diverse political interests in Nepal that the new state will be secular and have some type of federal structure, the substantive agreement ends there. ${ }^{1}$

The rhetorical similarities are deceiving, as ideology can vest the same words with different, even contradictory meanings. For example, during the Cold War, "democratic" had a profoundly different meaning in West Germany than it did in East Germany, which called itself the "German Democratic Republic" notwithstanding its socialist/communist ideology. ${ }^{2}$ Similarly, the rhetoric in the debate over the new judiciary in Nepal consistently calls for a judiciary that is "independent and accountable." But there is no consensus on what these terms mean, or should mean, in Nepal today.

These concepts of independence and accountability conflict with each other to some degree, but there is no one-size-fits-all approach to balancing

* Fulbright Scholar, University of Sarajevo, Bosnia and Herzegovina (2010-11); Associate Professor, Florida Coastal School of Law. Thanks to the American Bar Association Rule of Law Initiative, especially Dave Sadoff and Gopi Parajuli, for facilitating the July 2010 visit to Nepal and the meetings with key participants in the constitutiondrafting process. Much of the content of this article, and the perspective reflected in it, came directly from the consultations I was able to engage in with a variety of important players, from all parts of the political spectrum, during that visit to Kathmandu. Thanks to the Open Society Institute for funding. The views expressed in this article are, however, entirely those of the author.

1. Damakant Jayshi, Parties at Odds, Peace at Risk, INTER-Press SERVICE (Jan. 5, 2010), http://ipsnews.net/news.asp?idnews=49886 ("[T]he parties disagree on all major issues to be incorporated in the Constitution-preamble, fundamental rights, federal model, the number and nature of federal states and distribution of natural resources.").

2. Bureau of European \& Eurasian Affairs, Background Note: Germany, U.S. DEP'T STATE (Nov. 10, 2010), http://www.state.gov/r/pa/ei/bgn/3997.htm ("The G.D.R. established the structures of a single-party, centralized, communist state."). 
them. Despite talk about international best practices, ${ }^{3}$ the appropriate balance between these competing priorities cannot be imported from elsewhere. It must be determined with respect to Nepali culture, history, and politics. Both historical and ideological factors in present day Nepal tip the scales in favor of accountability at the expense of judicial independence. The challenge will be to find or create a judicial governance model that can heighten accountability while minimizing political or other interference with independent decision-making.

Similarly, competing definitions of "separation of powers" point in opposite directions on the issue of judicial review. However, by reaching beyond the deceptive rhetorical similarities and understanding the history and ideologies that inform the debate, it becomes clear that a new constitutional court, separate from the Supreme Court of Nepal, is the best path forward. A new institution, a departure from the status quo, is important for the reinvention of Nepali government.

If the parties can move beyond the rhetoric and appreciate each others' differing ideological stances, as well as the checkered history of Nepal's courts, there is room for consensus. Such a compromise, one that creates new institutions and enhances judicial accountability without infringing too much on judicial independence, is essential to reach an agreement on the new constitution and to establish a fair and effective Nepali judiciary.

\section{BACKGROUND}

\section{A. EXPERIENCE WITH THE 1990 CONSTITUTION}

Everything happening in Nepali politics today is, at some level, a reaction to Nepal's experience with the 1990 constitution (The Constitution of the Kingdom of Nepal) and the regime that existed under it. ${ }^{4}$ This includes the drafting of the judiciary provisions of the new constitution. ${ }^{5}$

Although Nepal flirted with constitutionalism for forty years, the first

3. Sagar Prasai, Nepal's Constituent Assembly Gets New Lease, but Politics Go Back to Square One, IN AsIA (June 2, 2010), http://asiafoundation.org/in-asia/2010/06/02/nepalsconstituent-assembly-gets-new-lease-but-politics-go-back-to-square-one/.

4. See generally United Nations Development Programme, The Interim Constitution of Nepal, 2063 (2007) as Amended by the First, Second and Third Amendments (2008), available at http://ccrinepal.org/files/downloads/37ddc770102c2dcf8b25892721729b5e.zip ("Among the shortcomings of the [1990] Constitution in the eyes of many were the insistence that Nepal is a Hindu kingdom; the inclusion of many important economic and social rights as 'directive principles' only, which means they were not able to be used as the basis for legal claims; inadequate provisions for civilian control of the army; excessive power given to the King; and provisions that were not clear enough about the King's powers, thus making it possible for those powers to be abused.").

5. Id. 
true and meaningful constitution in Nepal came in $1990,{ }^{6}$ establishing a constitutional monarchy, formally recognizing royal powers, and declaring Nepal a Hindu state. ${ }^{7}$ Dissatisfaction with the 1990 constitution fostered the Maoist insurgency, ${ }^{8}$ which mobilized those disenfranchised by the Hindu caste system, among others, to resist the constitutional regime. ${ }^{9}$ The Maoists ${ }^{10}$ became the primary critics of the regime and the champions of anyone aggrieved by it. ${ }^{11}$

Among the Maoists' complaints were problems with the Nepali judiciary. ${ }^{12}$ The 1990 constitution reflected, in large part, the prevailing international best practice of an independent judiciary governed by a judicial council. ${ }^{13}$ In theory, this is still the best constitutional structure for the Nepali judiciary. ${ }^{14}$ In practice, however, the Nepali judiciary under the 1990 constitution was dysfunctional and corrupt, or at least widely perceived to be. ${ }^{15}$ Against this historical backdrop, the advantages of an independent judiciary and an autonomous judicial council to govern it are more difficult to defend.

6. See generally David Pimentel, Constitutional Concepts for the Rule of Law: A Vision for the Post-Monarchy Judiciary in Nepal, 9 WASH. U. GLOB. STUD. L. REV. 283, 285-89 (2010) [hereinafter Constitutional Concepts].

7. Enayetur Rahim, Nepal: Government and Politic, The Constitution of 1990, in NEPAL \& BHUTAN: COUNTRY STUdies (Andrea Matles Savada, ed., 3d ed. 1993), available at http://memory.loc.gov/cgi-bin/query/r?frd/cstdy:@field(DOCID+np0101).

8. Alastair Lawson, Who are Nepal's Maoist Rebels?, BBC NEws, June 6, 2005, http://news.bbc.co.uk/2/hi/3573402.stm ("The disillusionment of the Maoists with the Nepalese political system began after democracy was re-introduced in 1990.").

9. Id. ("[The Maoist rebels] have stayed consistent ... in their demand for an end to Nepal's constitutional monarchy. Another key grievance of the rebels was the resentment felt by lower caste people against the authority wielded by the higher castes.").

10. The term "Maoists" is used throughout the article and denotes specifically the Maoist group that is active within Nepali politics.

11. Lawson, supra note 8 ("[A] substantial number of people in Nepal . . . see the Maoists as the only genuine alternative to the old, repressive social order.")

12. See, e.g., Maoists Wrath Against Nepal Judiciary, Telegraph NePal, Mar. 26, 2009, http://www.telegraphnepal.com/headline/2009-03-26/maoists-wrath-againstnepal-judiciary.

13. CONSTitution OF THE Kingdom OF NePAL, 1990, para. 93, § 1.

14. Constitutional Concepts, supra note 6.

15. Nepal Country Profile: Judicial System, Bus. AnTI-CorruPTION PORTAL, http://www.business-anti-corruption.com/country-profiles/south-asia/nepal/corruptionlevels/ judicial-system/ (last visited Mar. 27, 2011) (citing the Bertelsmann Transformation Index 2010 Nepal Country Report, BERTLERSMANN FOUND. (2009) http://www.bertelsmanntransformation-index.de/117.0.html?\&L=1). "The judiciary is perceived to be among the most corrupt institutions in Nepal. According to Bertelsmann Foundation 2010, court officials are perceived as the main facilitators of corruption." Id. 


\section{B. Political and IDEological CLIMATE}

The political revolution in Nepal that gave rise to the new constitution-making process is a direct product of the Maoist insurgency and the 2006 settlement of its demands that brought an end to the monarchy. ${ }^{16}$ Accordingly, the Maoists claim a right to sit at the table and dictate many of the terms of the government that will be established by the new constitution. If the elections had given them a clear majority, the Maoists would be able to do precisely that. However, the Maoists do not enjoy an outright majority in the present legislature, known as the Constituent Assembly (CA). Therefore, they do not have the power to control the constitution-making process. ${ }^{17}$ In fact, as of May 2009, the Maoists are no longer part of the coalition government. ${ }^{18}$ But because the Maoists have, by far, the largest bloc of any party in the CA, they remain a powerful political force. ${ }^{19}$ The upshot is that they must reach compromises with the other political parties for the constitution-making process to move forward.

Compromises will be difficult, however, given the ideological differences and mindset of the Maoists. Because the Maoists literally fought for change in Nepal, anything that smacks of the status quo is entirely unacceptable to them, ${ }^{20}$ including constitutional provisions for a judicial structure. While much of the drafting process appears to be mired in disagreements and political discord, the Maoists have already drafted a proposed constitution, presumably for discussion purposes. ${ }^{21}$ While it is not a polished document, it unambiguously sets forth the Maoists' policies and priorities for the new constitution. ${ }^{22}$

16. See Timeline: Nepal, BBC NEws, http://news.bbc.co.uk/2/hi/south_asia/country_ profiles/1 166516.stm (last updated Feb. 17, 2011, 15:42 GMT).

17. Prassi, supra note 3.

18. Id. ("The Maoists are the largest party in the Constituent Assembly, but a 22-party coalition has managed to push them to the fringes of national politics.").

19. Bureau of S. \& Cent. Asian Affairs, Background Note: Nepal, U.S. DeP'T STATE (Dec. 20, 2010), http://www.state.gov/r/pa/ei/bgn/5283.htm. In the 2008 elections, the Maoists secured 229 of the 601 seats, which was almost exactly twice as many as the next largest bloc (Nepali Congress Party with 115 seats) but far short of the majority they would need to control the Constituent Assembly outright. Id.

20. Interview by Ben Peterson with Manushi Bhattarai, Maoist Student Leader, (June 13, 2009), available at http://www.socialistunity.com/?p=4213 (characterizing the other parties in Nepal as "status quo-ist" and highlighting the challenge to fight the "status quo" forces).

21. S. Chandrasekharan, NEPAL: Draft Constitution of Maoists Unveiled, S. AsIA ANALYSIS GROUP (Mar. 18, 2009), http://www.southasiaanalysis.org//notes6/note502.html.

22. Id. ("While this document may not be the ultimate draft of the constitution, it reveals the mind and the intention of the Maoists of the type of configuration they are looking for in the new constitution."). 


\section{STATUS OF THE CONSTITUTION DRAFTING PROCESS}

The status of the constitutional drafting process changes daily. The CA, shortly after its creation under the Interim Constitution in 2008, set May 28, 2010, as the deadline to complete the new constitution. ${ }^{23}$ Delays, largely due to the political difficulties detailed above, made it impossible to meet that deadline. ${ }^{24}$ The CA voted in the closing minutes of its existence to extend its own life for another year, establishing a May 2011 deadline to produce a new constitution. ${ }^{25}$ While some have questioned the authority of the CA to take such actions, ${ }^{26}$ the practical necessity of these actions has calmed dissenting voices. If the government under the Interim Constitution had been allowed to expire, it would have left a vacuum of leadership and legal authority, a vacuum few wanted. ${ }^{27}$

Accordingly, there is a new deadline and hope for Nepal's constitutional future, although the process has been strained. Under the chairmanship of Nilambar Acharya, the Constitutional Committee (CC $)^{28}$ established a roadmap and timetable for the drafting process. In addition to the $\mathrm{CC}$, which oversees the entire process, ten thematic committees were appointed from the membership of the CA. Each committee had responsibility for certain subject matter in the new constitution and was charged with creating a concept paper detailing provisions on that topic that should be included in the constitution. Most of these committees attempted to arrive at some kind of consensus, with limited success and consequent

23. C. Balaji, Nepal 28 May 2010 Due Date for Nepal Constitution to be Finalized, WORLD NEwS FORECAST (May 28, 2010), http://www.newsahead.com/preview/ 2010/05/28/nepal-28-may-2010-due-date-for-nepal-constitution-to-be-finalized/index.php.

24. Id. ("Reuters reports that the political deadlock has delayed the preparation of a new constitution.").

25. By the time this article went to print, the new deadline of May 28, 2011, for the production of a new constitution had also been missed. On May 29, 2011, the political parties averted a crisis (see infra, note 27), reaching an agreement to extend the deadline another three months. Whether that deadline can or will be met is anyone's guess. Kiran Chapagain, Nepal Averts Crisis Over Constitution Deadline, N.Y. TIMEs, May 29, 2011, available at $\mathrm{http}: / / \mathrm{www} . n y t i m e s . c o m / 2011 / 05 / 30 /$ world/asia/30nepal.html.

26. United Nations Development Programme, supra note 4, at 116. Indeed, it seems obvious that the CA had no such authority, as the Interim Constitution specifies a term of two years for the CA. Id. But the Interim Constitution doesn't allow for new elections either. $I d$.

27. Balaji, supra note 23. "There are fears that Prime Minister Madhav Kumar Nepal will declare a state of emergency if the Constituent Assembly fails to deliver [a constitution] by the due date. An unmet deadline for a constitution acceptable to all parties could trigger another civil war, while increasing India's and China's tug-of-war for the Himalayan Kingdom." Id.

28. NC Leader Elected Head of Nepal Constitution-Drafting Body, ZEE NEWs, http://www.zeenews.com/news559032.html (last updated Aug. 28, 2009 4:24 PM). 
delay. ${ }^{29}$ In contrast, the forty-three member Committee on the Judicial System took an up-or-down vote on each proposed revision ${ }^{30}$ and was therefore able to complete its Report Preliminary Draft with the Concept Paper (CJS Concept Paper) promptly, by the fall of 2009. ${ }^{31}$ The problem with the Committee on the Judicial System's approach was that the end product did not reflect consensus and engendered a great deal of opposition even within the committee. Seven dissenting opinions are appended to the CJS Concept Paper, six of them signed by a bloc of nineteen committee members detailing their objections to the paper's recommendations. ${ }^{32}$

Committee reports and concept papers are not the definitive word on each subject. They must go through the $\mathrm{CC}$, which draws from them but is not bound by them in drafting the constitution. Indeed, the $\mathrm{CC}$ will have to make changes, as some elements of the concept papers are in direct conflict. For example, the Report and Concept Paper of the Committee on State Restructuring specifically calls for the creation of a "Constitutional Court" to resolve questions of constitutional interpretation. ${ }^{33}$ It even specifies the composition of that court. ${ }^{34}$ On the other hand, the CJS Concept Paper did not provide for the creation or existence of such a court. ${ }^{35}$ Accordingly, the Reports need to be harmonized, and until then, the underlying issues remain open for negotiation and resolution through ongoing dialogue. These issues are considered by the powerful "Gaps and Overlaps Committee," which is already appointed for the purpose of reconciling inconsistencies, before going to the $\mathrm{CC}$ for final resolution. ${ }^{36}$ Whether there will be a

29. Whither Constitution Writing?, NePALI TIMES, May 28, 2010, $\mathrm{http} / / / \mathrm{www}$. nepalitimes.com.np/issue/2010/05/28/ConstitutionSupplement/17125. As of May 28,2010 , which was the original deadline for completion of the constitution, "only three committees' draft papers ha[d] been passed unanimously." Id.

30. Interview with Kumar Regmi, Constitutional Lawyer, in Kathmandu, Nepal (July 18, 2010), (notes on file with the author). The Maoists' proposals prevailed in the Committee on the Justice System, for the most part, because the Madhesi party representatives chose to vote with the Maoists on most issues. Id.; see COMM. ON JUDICIAL Sys. To THE Constituent Assembly, A Report Preliminary Draft with tHe CONCEPT PAPER (2009), available at http://www.ccd.org.np/new/resources/concept_paper_Judiciary_ System_ENG.pdf [hereinafter CJS CONCEPT PAPER].

31. Id.

32. Id. at 68-84. Eighteen committee members signed the seventh dissenting opinion. Id. at 68 .

33. CONSTITUENT AsSembly, Restructuring of the STATE and Distribution of State POWER COMmitTeE, REPORT ON CONCEPT PAPER AND PRELIMINARy DRAFT art. 11, $\S 11$ (2010), available at http://www.ccd.org.np/new/resources/Concept_Paper_Re structuring_State_GTZ_ENG.pdf.

34. Id. at 38.

35. CJS CONCEPT PAPER, supra note 30.

36. See Constitution Building e-Bulletin: What's Happening at the Constituent Assembly (CA), Center for Const. Dialogue, at para. 6 (May 1, 2010), http://ccd.org.np /new/index.php?newsletter_detail_id=16 (referencing the role of the Gaps and Overlaps 
Constitutional Court, separate from the Supreme Court, and what jurisdiction it may have, remain open questions.

\section{COMPETING CONCEPTS FOR THE NEPALI JUDICIARY}

\section{A. IDEOLOGY AND THE ROLE OF THE JUDICIARY}

The vision of the Maoists, who represent the political left in Nepal, differs significantly from the Marxist-Socialist views of Chairman Mao Zedong or of the Soviet-era Warsaw Pact nations. The International Crisis Group described them as follows:

Despite having an authoritarian outlook, the Maoists
maintained a culture of debate within their party; key issues
have been widely discussed and hotly contested. From the
end of the 1990 s, they have moved gradually toward a
more moderate stance. They changed positions in
acknowledging the 1990 democracy movement as a success
(they had earlier characterised it as a "betrayal"), in
abandoning the immediate goal of a Mao-style "new
democracy" and, in November 2005, by aligning
themselves with the mainstream parties in favour of
multiparty democracy.

While the Maoists do not advocate for a traditional communist regime, their perspective and thetoric are inevitably infused with Marxist ideology, which, in turn, informs their perception of the role of the judiciary. On Nepal's political right is the Nepali Congress Party, which controlled the government during most of the period that the country was operating under the 1990 constitution. The Unified Marxist-Leninists, popularly viewed as moderates, have been in the middle as the third largest party, ${ }^{38}$ but there are as many as twenty other parties operating in Nepal. ${ }^{39}$

In common law regimes, the judiciary historically has protected the people from the abuses of government. ${ }^{40}$ This Western perspective defines

Committee).

37. INT'L Crisis GrP., NePal's MaOISTS: PuRISTS OR Pragmatists?: ASIA RePORT No. 132, at i (2007), available at http:/www.crisisgroup.org/ /media/Files/asia/south-asia/nepal/ 132_nepal_s_maoists purists_or_pragmatists.ashx.

38. See Kiran Chapagain \& Jim Yardley, Nepal's Parliament Fails in 5th Try to Select Prime Minister, N.Y. TIMES Aug. 23, 2010, http://www.nytimes.com/2010/08/24/world/ asia/24nepal.html.

39. See Prasai, supra note 3 (referencing a twenty-two party coalition in the CA, excluding the Maoists).

40. John Henry Merryman \& Rogelio Pérez-Perdomo, The Civil Law Tradition: An INTROduction to the Legal. Systems of EuRope AND Latin AMERICA 17 (3d ed. 2007) ("In the United States and England . . there was a ... judicial tradition . . in which judges 
justice on the micro level. Any attempt to subvert individual justice in pursuit of higher societal goals is roundly condemned as evil.

From the Marxist point of view, however, it is not the courts that protect the people (individually) from government, but rather the government that protects the people (collectively) from exploitation by capitalists. ${ }^{41}$ Government is not a threat to justice or to the rights of the people; government is the source of social justice and the protector of the people. ${ }^{42}$ From this perspective, there is no reason to expect the judicial branch to be independent from the political branches of government. Rather, the judicial branch is perceived as another arm of the government, similarly committed to carrying out the government's agenda. ${ }^{43}$

Indeed, the Soviet Union and other communist-bloc nations shared this concept of the judicial branch. Dallin Oaks, former justice of the Utah Supreme Court, recently recounted his experience with Soviet-style justice:

I have thought of how our system contrasts with that of the now defunct Soviet Union. During my years as president of BYU [Brigham Young University] (1971-80), I hosted the chief justice of the Supreme Court of the Soviet Union, who was touring the United States in that Cold War period. In a private one-on-one discussion, I asked him how the Soviet system really worked in a highly visible criminal case, such as where a person was charged with an offense like treason or other crimes against the state. He explained that on those kinds of cases they had what they called

had often been a progressive force on the side of the individual against the abuse of power by the ruler.").

41. See generally Karl MarX \& Fredrich Engels, The Communist Manifesto (1848).

42. Nikolai Bukharin \& Yevgeni Preobrazhensky, The ABC of Communism § 23 (1920) ("For the realization of the communist system the proletariat must have all authority and all power in its hands. The proletariat cannot overthrow the old world unless it has power in its hands, unless for a time it becomes the ruling class. Manifestly the bourgeoisie will not abandon its position without a fight. For the bourgeoisie, communism signifies the loss of its former power, the loss of its 'freedom' to extort blood and sweat from the workers; the loss of its right to rent, interest, and profit. Consequently the communist revolution of the proletariat, the communist transformation of society, is fiercely resisted by the exploiters. It follows that the principal task of the workers' government is to crush this opposition ruthlessly.").

43. Id. at $\S 71$ ("In fine, in the long succession of civil and criminal affairs, the proceedings of the courts must be conducted in the spirit of the new socialist society which is in course of construction. For these reasons the Soviet Power did not merely destroy all the old machinery of justice which, while serving capital, hypocritically proclaimed itself to be the voice of the people. It went farther, and constituted new courts, making no attempt to conceal their class character. In the old law-courts, the class minority of exploiters passed judgement upon the working majority. The law-courts of the proletarian dictatorship are places where the working majority passes judgement upon the exploiting minority."). 
"telephone justice." Judges conducted the trial and heard the evidence and then went back to their chambers and had a phone call from a government or party official who told them how to decide the case.

I am grateful that, whatever difficulties we have in our system of justice-and there are many-we are still far away from what he called "telephone justice." What stands between us and that corruption of the judicial system ... is the independence of our state and federal judges. ${ }^{44}$

Particularly shocking to Western sensibilities is the fact that the Soviet Chief Justice explained the telephone justice system openly and without apparent embarrassment. Most Westerners would unhesitatingly join in Oaks' assessment of that practice as an indicator of a corrupt judicial system.

But again, from the Marxist perspective, the government, or perhaps more specifically the party, is the guardian of the people's rights and interests; no one else should make the decision in sensitive cases. According to this view, entrusting such decisions to individual judges may result in decisions that are in conflict with the best interests of the people overall. In the post-communist state, telephone justice is still talked about. ${ }^{45}$ Although it is generally decried in post-communist retrospect, it was accepted as a fact of life, perhaps even a necessary one, under communist regimes. ${ }^{46}$ The Marxist will not allow the decision of an individual judge to frustrate the government's pursuit of the best interests of the people. By ideological contrast, the Western capitalist will not let the government's political agenda frustrate justice in an individual case.

The differences may be characterized in terms of trust. Judicial independence places enormous trust in judges, expecting them to do the right thing and to do justice even when there are compelling political or personal reasons to do otherwise. Western society's embrace of judicial independence reflects a distrust of government, even of majoritarian

44. Elder Dallin H. Oaks, Church of Jesus Christ of Latter-Day Saints, Constitution Day Speech at the Salt Lake Tabernacle: Fundamentals of our Constitutions (Sept. 17, 2010), available at http://newsroom.lds.org/article/fundamentals-of-our-constitutions-elder-dallinh-oaks.

45. Alena Ledeneva, Behind the Façade: "Telephone Justice" in Putin's Russia, in DiCTATORSHIP OR REFORM? THE RULE OF LAW IN RUSSIA 24-36 (2006), available at http://se2.isn.ch/serviceengine/Files/ESDP/26627/ichaptersection_singledocument/036BC43 7-221A-4FC3-9EC3-E82BDECA7084/en/Chap_3_Ledeneva.pdf.

46. Id. (citing Peter Solomon, Jr., Soviet Politicians and Criminal Prosecutions: The Logic of Intervention, in CRACKS IN THE MONOLITH (James Millar ed., 1992)). "Communist governance resulted in what Peter Solomon has called the 'logic of intervention' or the logic of the 'directive from above' where the Communist party had the last word." Id. 
government. The belief is that such governments will exploit and victimize unpopular minorities unless they are subject to the checks and balances that come from an independent judiciary.

This idea is reflected in Alexis de Tocqueville's Democracy in America, which recognizes the role of the judiciary in protecting the minority from the "tyranny of the majority." foundational to the American ideological concept of the judiciary: because of their independence from majoritarian politics, only judges can be effective guardians of the rights of unpopular minorities.

In contrast, meetings with prominent Maoists involved in the constitution drafting process revealed that they have much greater trust in the government than in "independent" judges. ${ }^{48}$ In Nepal, unlike Soviet-era socialist governments, this trust is not a blind faith in the Communist Party. Whatever else may appear in the new Nepali constitution, it will certainly provide for a parliamentary system where the government is a direct product of popular elections. ${ }^{49}$ The Maoists trust the legislature more than the judiciary because the legislature is accountable to the people. ${ }^{50}$ Independent judges, unaccountable to anyone, simply cannot command that type of confidence $;^{51}$ in the Maoists' view, a judiciary that is independent of parliamentary control is inherently undemocratic and, therefore, not to be trusted.

Summarizing, and perhaps oversimplifying, Western ideology trusts judges to do the right thing as long as they are not pressured by political forces to do otherwise. Maoist ideology in Nepal assumes judges will do the wrong thing unless pressured by political forces otherwise. These conflicting assumptions demand fundamentally different policy prescriptions for Nepal's judicial structure and are not amenable to compromise.

47. See generally AleXIS DE TOCQUEVILLE, DEMOCRACY IN AMERICA ch. 15 (1835). The term "tyranny of the majority" was further popularized by John Stuart Mill, who used it in his essay "On Liberty" (1859). See JOHN STUART MILL, ON LiBERTY (Bartleby 1999).

48. Interview with Ek Raj Bhandari, CA Member and Member of the Gaps and Overlaps Committee, in Kathmandu, Nepal (July 14, 2010) (notes on file with author). Mr. Bhandari gave a passionate explanation of the Maoist perspective on judicial independence; he pitched it in terms of his confidence in the democratic process and advocated entrusting the judiciary to the people and making it accountable to the people by placing it squarely under the power and control of those most responsive to the people: the elected legislature. See also Interview with Khim Lal Devkota, CA Member and Member of the Committee on the Judicial System, in Kathmandu, Nepal (July 16, 2010) (notes on file with author).

49. See Prasai, supra note 3 (noting that the Maoists have moderated their position and support a multiparty government now).

50. Interview with Ek Raj Bhandari, supra note 48.

51. Interview with Khim Lal Devkota, supra note 48. (Mr. Devkota argued that the judiciary must be accessible and transparent; citizens must feel like the judiciary belongs to them and that they want to support it and strengthen it because it gives them justice.). 


\section{B. JUDICIAL INDEPENDENCE V. JUDICIAL ACCOUNTABILITY}

Scholars have paid considerable attention to the tension between judicial independence and judicial accountability, often attempting to strike an appropriate balance between these two competing policies. ${ }^{52}$ This tension exists because a fully independent judiciary is accountable to no one and can render controversial or unpopular judgments without fear of repercussions. On the other hand, an accountable judiciary is answerable for its actions and, therefore, can never be truly independent. ${ }^{53}$ As has been previously argued, ${ }^{54}$ there is no one-size-fits-all balance to strike between judicial independence and judicial accountability. Nepal presents a compelling case.

Consider the two attributes Westerners prize most in the context of judicial independence and accountability: judges who demonstrate (1) integrity to recognize their ethical obligations and uphold them, and (2) courage to withstand outside pressure in rendering their decisions. ${ }^{55}$ Accountability, in the form of disciplinary mechanisms for miscreant judges is important to encourage integrity; independence, in the form of structural protections for judges, insulating them from repercussions for their decisions, is important to bolster judicial courage. ${ }^{56}$ Aside from structures to protect their independence or disciplinary regimes to hold them accountable, every judge comes to the job with a personal endowment of both courage and integrity, an endowment that can be represented as a unique point on the figure below:

52. Symposium, Judicial Independence and Judicial Accountability: Searching for the Right Balance, 56 CASE W. RES. L. REv. 899 (2006). In 2006, the Case Western Reserve Law Review conducted a symposium entitled "Judicial Independence and Judicial Accountability: Searching for the Right Balance." Id. The title of the symposium alone betrays the nearly axiomatic understanding that these two principles are in fundamental conflict and that a balance must be struck between them.

53. David Pimentel, Reframing the Independence v. Accountability Debate: Defining Judicial Structure in Light of Judges' Courage and Integrity, 57 CLEv. ST. L. REv. 1,18 (2009) [hereinafter Reframing the Debate].

54. Id. at 31-32.

55. Id. at $20-23$.

56. Id. at 29 . 


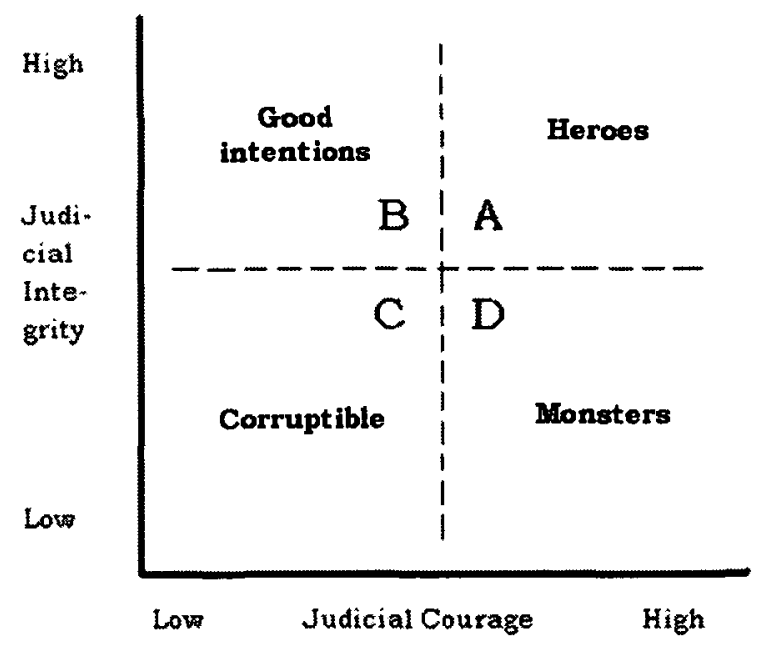

Fig. 1 -- Plotting Judicial Courage and Integrity on a Graph

[I]n the Northeast quadrant (Quadrant A), we find the judges of the highest integrity and the highest courage. These are our "heroes." In the Northwest quadrant (Quadrant B), we find judges who want to do the right thing, but are vulnerable to outside threats and pressures; their integrity is high, but their courage is lacking. Quadrant C, in the Southwest, includes the "corruptible" judges, whose integrity is dubious, and who, lacking courage, are susceptible to pressure. Here is where you might find judges who pander to the whims of the executive branch or [who might] even be in the pocket of the mob. They are not bent on pursuing their own corrupt agenda (see Quadrant D, infra) as they lack the courage for such an enterprise, but are manipulable, and may well end up doing the bidding of others. In the Southeast (Quadrant D) we find the scariest of all, the judges with low integrity and ample courage; these are what Judge Noonan described as "Monsters" in his book on judicial ethics--judges who boldly pursue their own corrupt objectives. ${ }^{57}$

Using this model, one can see that strengthening structural protections for judicial independence may do more harm than good if the judges are

57. Reframing the Debate, supra note 53, at 27-28 (citing THE RESPONSIBLE JUDGE: REadings in Judicial ETHics 35-47 (John T. NOONAN, JR. \& KenNETH I. Winston eds., 1993)). 
located in the bottom half of the graph. A judge who lacks integrity will only be emboldened in his corruption by a regime that immunizes him from outside pressures. Structural protections for judicial independence are helpful only if the judges have already demonstrated a reasonable degree of integrity. The Western system that trusts judges assumes this threshold level of integrity; the Maoist ideology does not.

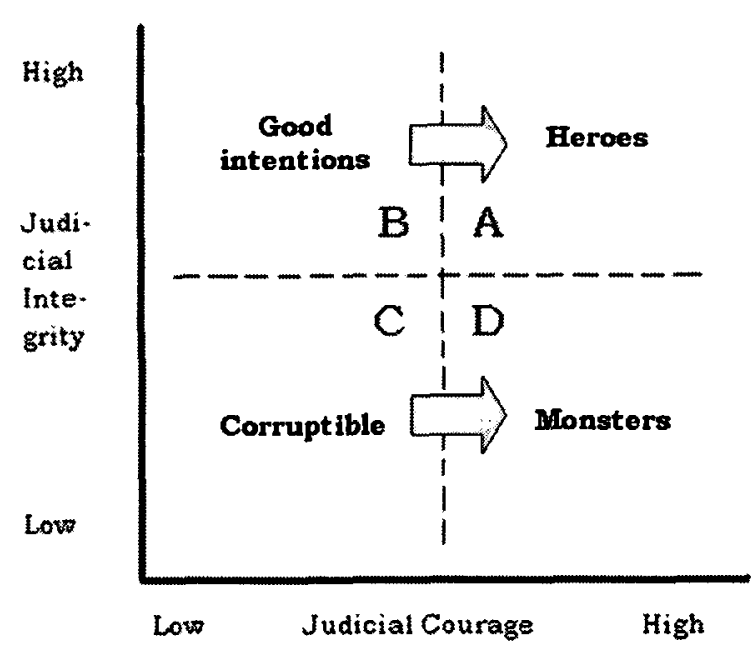

Fig. 2 -- Impact of strengthened structural protections for judges ${ }^{58}$

\section{HISTORICAL BAGGAGE IN THE NEPALI JUDICIARY}

History complements ideology as a critical and perhaps controlling factor in the future of the Nepali judiciary. The 1990 constitution did afford the judges a high degree of independence. That independence was strengthened further by the fact that the disciplinary body, the judicial council, rarely exercised its power to police the judiciary. ${ }^{59}$ The result was, according to popular perception, a judiciary that earned the confidence of no one and a bench that distinguished itself more by its corruption than by anything else. ${ }^{60}$ The Western model of trusting judges failed to work. The general perception in Nepal is that the judges were unworthy of such trust. ${ }^{61}$

58. Id. at 29-30.

59. Interview with Khim Lal Devkota, supra note 48. Mr. Devkota cited the failures of the Judicial Council, which, he said, despite obvious corruption throughout the system has never removed a judge in twenty years. This author has not attempted to verify the claim, but it is worth noting that this perception comes from a member of the CA and the Committee on the Judicial System. See id.

60. See Nepal's Judiciary Is Most Corrupt: TI Report, NePAL BIZ News.COM (May 25, 2007), http://www.nepalbiznews.com/newsdata/Biz-News/judicial.html (citing Transparency INTERNATIONAL, GlOBAL CORRUPTION REPORT: CORRUPTION IN JUdiCIAL 
Unsurprisingly, the popular outcry in Nepal-and not just from the Maoists-is for a judiciary that is accountable. ${ }^{62}$ Judicial independence advocates cannot effectively argue that the Nepali people should trust their judges and accord them the independence to do the right thing. Trusting the judges too much and giving them too much independence is widely perceived by Nepali citizens as one of the sources of the present problem.

\section{THE RHETORICAL GAP}

No one in the current Nepali constitutional debate is openly advocating against an independent judiciary. The rhetoric from all sides is consistent that judicial independence is desirable. The CJS Concept Paper contains thirteen separate references to judicial independence, mostly justifying provisions on the grounds that judicial independence requires them, including the following: judges."

"The constitution has to provide functional independency to

"As the judicial independency is an essential condition for the fair justice, the person who is dispensing justice should also be fair, competent, capable, impartial. ${ }^{.64}$

"The meaning of the independence of judiciary refers not only to be free from intervention in the judicial process by any person, authority or bodies other than judiciary, but also free from influence of any level or office-bearer of and within the judiciary itself.,"65

"The judicial independency is an essential condition in order to carry out judicial proceeding according to law."

Despite these concessions on the importance of judicial independence, the CJS Concept Paper itself entrusts the governance of the judiciary, including all appointments, oversight, discipline, and removal, to a Special Committee of the Legislature (Special Legislative Committee) ${ }^{67}$

SYSTEMS (2007)) ("A country report on judicial corruption released . . by Transparency International Nepal said Nepal's judiciary is one of the most corruption-affected sectors in the country. The Global Corruption Report 2007 prepared by senior advocate Krishna Prasad Bhandary on behalf of Transparency International (TI) said though corruption and irregularities are rife in Nepal's judiciary, initiatives are not being taken to curb such malpractices.").

61. See generally, Sewanta Kattel, Local Level Perception of Corruption: An Anthropological Inquiry, 3 DHAULAGIRI J. Soc. \& ANTHROPOLOGY (2009) (analyzing the sources of the public perception of public corruption, including judicial corruption).

62. Interview with Ek Raj Bhandari, supra note 48; interview with Khim Lal Devkota supra note 48.

63. CJS CONCEPT PAPER, supra note 30 , at 15.

64. Id. at 16 .

65. Id. at 31 .

66. Id. at 27 .

67. Id. at 39 . 
This Special Legislative Committee is conceived as an eleven-person body, chaired by the Deputy Speaker of the Legislature and composed of the Minister for Law and Justice and nine additional members of the legislature $^{68}$ The rationale for the Special Legislative Committee is articulated in the CJS Concept Paper in terms of "democratiz[ing]" the courts:

The foundation of Democracy is the Civilian Supremacy. As the legislature is a representative body and also exercises the sovereignty of the people, the voice of people should only be reflected via this body. One of the major reasons behind the judiciary in the past that the people never realized ownership over it was lack of judiciary's responsibility to the people. Therefore, it is necessary to democratize the judiciary according to the present context. $^{69}$

As noted, a substantial minority of the Committee on the Judicial System dissented from the CJS Concept Paper on a variety of issues. One of those dissents, which objects to the power of the Special Legislative Committee, strongly invokes the concept of judicial independence:

[I]f judges are recommended by the legislature or any committee at the legislature, and approval or ratification of the appointment by the legislature on the recommendation, the judiciary becomes likely a body under the legislature. In a democratic system under the principle of separation of power, the power of the states is divided in which the legislature makes laws, the executive implements the laws and the judiciary interprets the laws. Provided that, if the legislature holds the sole power of the State to form an organ of the state or holds power to supervise, control and monitor the state organs, the judiciary can not be imagined as an independent and competent. Consequently, the country heads toward dictatorship and anarchism. While writing a written Constitution, if the legislative [sic] is made more powerful than the Constitution itself, there is highly a chance of centralizing the power at the legislature, which we never have wished. ${ }^{70}$ 
The ideological divide becomes apparent in this debate, even though both sides are invoking principles of democracy, independence, and accountability. Notwithstanding the predictions of doom in the dissenting opinion, the Maoists do appear to believe in some degree of parliamentary supremacy. Maoists argue that the check on the legislature's power or abuse thereof rests with the people who can always vote out a legislature that abuses the public trust. Maoists believe that one cannot trust an unaccountable judiciary to play such a responsible role. ${ }^{71}$

The Nepal Bar Association (NBA) has also staked out a strong position against the CJS Concept Paper by publishing its own position paper on judiciary issues. It decries the CJS Concept Paper's approach for its failure to "uphold the principle of independence of judiciary and the separation of powers which is one of the fundamental pillars of democracy." 2 The NBA position paper goes on to "emphasize[] that legislative interference (federal or provincial) with judicial appointments and dismissals is not acceptable." ${ }^{, 73}$

The President of the NBA has expressed his confidence-based on conversations he has had with the highest level Maoist leaders-that even the Maoists share the NBA's commitment to an independent judiciary. ${ }^{74}$ However, the concrete proposals coming from the Maoists suggest that judicial independence to the Maoists means something very different from what it means to the NBA.

\section{SEPARATION OF POWERS}

Both the dissenting opinion and the NBA position paper make specific reference to the concept of separation of powers, the latter identifying it as "one of the fundamental pillars of democracy." While the Maoists speak of independence and accountability, they do not speak of separation of powers, much less tout it as a pillar of democracy. The CJS Concept Paper illustrates that the Maoist concept of democracy militates against separation of powers and favors bringing the judiciary under the control of the legislature as a means of "democratiz[ing]" the judiciary.",76

71. Interview with Ek Raj Bhandari, supra note 48.

72. Nepal Bar Ass'N, The Judicial System UNder Nepal's New Constitution 11 (2010).

73. Id.

74. Interview with Mr. Prem Bahadur Khadka, NBA President, in Kathmandu, Nepal (July 13, 2010) (notes on file with author).

75. CJS CONCEPT PAPER, supra note 30, at 77; NEPAL BAR Ass'N, supra note 72, at 11.

76. CJS CONCEPT PAPER, supra note 30 , at 39 ("As the legislature is a representative body and also exercises the sovereignty of the people, the voice of people should only be reflected via this body. . . . [I]t is necessary to democratize the judiciary according to the present context."). 
The concept of separation of powers, raised first in the discussion of judicial appointments, arises again in the context of constitutional interpretation. The question of who should have the power of constitutional interpretation in Nepal is sufficiently controversial and important to deserve mention here. In the United States, constitutional interpretation is entrusted to the Supreme Court. Americans are untroubled by the fact that by making interpretive judgments the Court may actually be making law. ${ }^{77}$ In common law jurisdictions, the concept of judge-made law is neither novel nor threatening. ${ }^{78}$ This concept follows the traditional role of the common law judiciary articulated above: to protect the public from the government. Indeed, the power of the judiciary was invoked historically in common law England as a check on the power of the king. ${ }^{79}$

The tradition of the civil law is profoundly different. Judges were expected to apply the law but not interpret it. ${ }^{80}$ From this perspective, ambiguities in the law are to be referred to legislative bodies, not judiciaries, for clarification. ${ }^{81}$ The rationale is that such interpretation and clarification is inherently a legislative act. ${ }^{82}$ This ideology was established under Roman legal tradition and revitalized by the French revolutionaries. French revolutionaries did not see the judiciary as a champion of the rights of the people, as in England, but rather as a barrier and a threat to democratic governance. ${ }^{83}$

Under civil law tradition, it is inappropriate to entrust issues of interpretation, especially of the constitution, to the regular courts. Civil law jurisdictions have developed separate institutions for such interpretation. ${ }^{84}$ In many of these countries, constitutional courts operate independently from a supreme court and address issues of constitutional interpretation, leaving a supreme court to function simply as the ultimate court of appeals-the court of last resort. ${ }^{85}$ Conceptually, these constitutional courts

77. Merryman \& Pérez-Perdomo, supra note 40, at 17 ("The fear of judicial lawmaking [in the United States and England] . . . did not exist. On the contrary, the power of the judges to shape the development of the common law was a familiar and welcome institution.").

78. $I d$.

79. Id.

80. Id. at 30 ("[T]he function of the judge would be limited to selecting the applicable provision of the code and giving it its obvious significance in the context of the case ...."); Id. at 39 ("[Prussian] judges were forbidden to interpret the code.").

81. Id. at 40 ("A new governmental organ was created by the legislature and given the power to quash incorrect interpretations by the courts .... [The Tribunal of Cassation] was not a part of the judicial system, but rather a special instrument created by the legislature to protect legislative supremacy from judicial usurpation.").

82. Id. at 30 ("Experience with the pre-revolutionary courts had made the French wary of judicial law-making disguised as interpretation of laws.").

83. Id. at 35-36.

84. Id. at 37-38.

85. Id. at 37-38; see also, e.g., Differences Between the Constitutional Court and the 
were not to be courts at all and were not considered to be part of the judicial branch, although over time they have assumed an increasingly judicial character. ${ }^{86}$ Thus, although judicial review of legislative action has been a sacred element of common law jurisprudence since Marbury v. Madison, ${ }^{87}$ judicial review, like any act of judicial interpretation, would be considered a violation of separation of powers under the civil law tradition.

The CJS Concept Paper and the Maoists' draft both provide that issues of constitutional interpretation will be entrusted to the Special Legislative Committee, which is a legislative body. ${ }^{88}$ The NBA disagrees, invoking the principle of separation of powers:

The NBA holds the position that the judiciary, and, ultimately, the Supreme Court, should be the final body to interpret the law, including the constitution, as per the principle of the separation of powers and independence of the judiciary. Accordingly, the NBA expresses grave concern with the provision of the JS Concept Paper with respect to the interpretation of constitution by a committee of the federal legislature. ${ }^{89}$

The NBA view, therefore, reflects the perspective and ideology of a common law jurisdiction. Such a perspective may not be surprising given the profound influence of India in the region and the assistance and support the NBA has received from Canadian sources. ${ }^{90}$

Supreme Court of Justice, NISGUA, available at http://www.nisgua.org/themes_campaigns/ impunity/Differences\%20Between\%20Constitutional\%20Court\%20and\%20Supreme $\% 20$

Court\%20of\%20Justice.pdf (describing the different jurisdiction of these two bodies in Guatemala).

86. MERRYMAN \& PÉREZ-PERDOMO, supra note 40 , at 37-38.

[T] hese special [constitutional] courts, which are not a part of the ordinary judicial system and are not operated by members of the ordinary judiciary, were established in response to the civil law tradition that judges ... cannot be given such power to review statutes for constitutionality. In time, many of these institutions have acquired judicial character, particularly in jurisdictions that follow the Germanic civil law tradition, and in Latin American civil law tradition.

Id. at $134-42$.

87. 5 U.S. 137 (1803).

88. CJS Concept Paper, supra note 30, at 39; Constitution of the PeOPLE's Federal REPUBLIC OF NEPAL, (2067/2008) (Proposed Integrated Draft) $\S 172$, at 69, available at http://southasiarev.files.wordpress.com/2011/01/new_draft_nepal_consitution.pdf.

89. NEPAL BAR Ass'N, supra note 72, at 13.

90. See Nepal Bar association: Developing Democracy In NePal (DDN-II), http://nba-cba.org.np/new/index.php?option=CMS\&task=detail\&cid=5, (detailing the cooperation and support of the Canadian Bar Association with and for the Nepal Bar Association). 
A lawyer from a civil law jurisdiction would likely conclude, however, that entrusting constitutional interpretation to the supreme court would be the more serious violation of separation of powers. It is the legislature, after all, that decides what the law is; the courts, with judges operating as mere functionaries, are empowered only to apply the lawideally mechanically, to the extent that is possible - to individual cases.

There is nothing sacred about entrusting constitutional interpretation issues to the Supreme Court of Nepal. While the principle of constitutional supremacy is a vital one, fundamentally in conflict with the legislative supremacy favored by the Maoists' and CJS Concept Paper's proposals, there is nothing offensive to the core principles of judicial independence in the creation of a separate constitutional court. ${ }^{91}$ Further, there may be great advantages to such a court, particularly in its potential to attract consensus both from separation of powers advocates and those who find the status quo unacceptable.

\section{WHERE TO GO FROM HERE? RECONCILING IT ALL}

Ultimately, any compromises that are reached for the new Nepali judiciary must reflect the ideological and historical forces at play in Nepal. The largely independent judiciary of the past two decades utterly failed to win public confidence and trust.$^{92}$ The new judiciary for Nepal must be more accountable and, thus, necessarily less independent than in the past. The status quo is entirely unacceptable; serious changes have to be made, which will come largely with greater accountability measures. Even the NBA position paper - the fiercest defense of judicial independence seen in the debate-speaks strongly about the importance of accountability:

In the survey conducted by the NBA the overwhelming majority of respondents opined that judiciary should be established as a corruption-free sector, and the code of conduct should be implemented strongly against judges. It is obvious that so as to maintain accountability of the

91. Most models for constitutional courts in other countries place the court reasonably beyond the control of any one branch of government. The Indonesian Constitutional court, for example, is composed of nine justices put forward by the three branches of government: three by the President, three by the Supreme Court, and three by the legislature (the People's Representative Council). Mohammad Mahfud, Separation of Powers and Independence of Constitutional Court in Indonesia, at 9, (paper presented by the Chairman of the Indonesian Constitutional Court at the 2nd Congress of the World Conference on Constitutional Justice in Rio de Janeiro, Brazil on Jan., 16-18, 2011), available at http://www.venice.coe.int/ WCCJ/Rio/Papers/INA_Mahfud_E.pdf.

92. See Nepal's Judiciary Is Most Corrupt: TI report, supra note 60. 
judiciary, the effective implementation of codes of conduct and impeachment proceedings must be strictly enforced. ${ }^{93}$

However, the judiciary must also not be held accountable to majoritarian forces. Even if the Maoists prefer to trust the people and see themselves as the champions of the oppressed, Nepal has a long and ugly history of discrimination against unpopular and disenfranchised minorities. ${ }^{94}$ The majority can be expected to protect the rights of the majority through legislative action, but someone must guarantee the rights of Nepal's minorities, including women, Dalits, religious minorities, and a host of ethnic subgroups.

The international consensus on best practice for enforcing judicial accountability is to entrust enforcement of ethics codes, and the policing of judicial misconduct and corruption to an independent judicial council. ${ }^{95}$ However, the failure of the previous judicial council to perform this function ${ }^{96}$ and the political imperative to avoid anything that appears to perpetuate the status quo, ${ }^{97}$ militate in favor of creating a new institution to assume this role. The ideological and historical forces at play in Nepal require no less.

Notwithstanding the Maoists' best intentions, however, this new institution should not be a body of the legislature. A better approach would be for the new constitution to create a Judicial Complaints Commission (JCC) within the judicial branch, empowered to investigate charges of judicial misconduct and recommend disciplinary action, including removal of judges found to violate ethical standards. This JCC may be appointed with participation by political actors, but once appointed it should remain one step removed from majoritarian political forces. ${ }^{98}$ Otherwise, the JCC could be pressured to harass judges who render unpopular decisions that

93. NePal Bar Ass'N, supra note 72, at 14.

94. See, e.g., Press Release, Asian Human Rights Comm'n, NEPAL: Implementation of Anti-Discrimination Laws (July 24, 2010), available at http:/www.scoop.co.nz/ stories/WO1007/S00470/nepal-implementation-of-anti-discrimination-laws.htm (giving an assessment of the failure to protect human rights of Dalits in Nepal).

95. The author made precisely this recommendation in an earlier article about the Nepali judiciary. Constitutional Concepts, supra note 6, at 294-310. This article reconsiders and amends that position. 59.

96. Interview with Khim Lal Devkota, supra note 48; see supra text accompanying note

97. See supra text accompanying note 20 .

98. There are various ways to insulate JCC members from political interference. One option might be to select JCC members from the ranks of the judiciary, have them serve one term on the JCC, and then return to a secure post in the judiciary. Under this option they need not worry about pleasing the appointing authorities since they cannot be renewed anyway. Further, JCC members need not worry about using their influence to ingratiate themselves to future employers since they have a secure post in the judiciary to which to return in any case. 
protect the rights of minorities or judges whose politics or interests are at odds with the ruling party.

Constitutional interpretation should also be at least one step removed from the legislature, lest constitutional standards become subject to the whims of the majority. Again, the judiciary's inability to muster public confidence in the past weighs in favor of a new institution, such as a constitutional court, to perform this role. This new institution, without a history of corruption or politicization, may be the best hope for sound constitutional administration in a new Nepal.

\section{CONCLUSION}

Nepal must come together and find common ground and consensus for the structure and character of its new government, which will be reflected in the drafting of the new constitution. The debate over the structure and role of the judiciary is divisive, is exacerbated by all sides using similar rhetoric to argue for very different, even inconsistent approaches.

Reconciliation of this war of words and ideas requires an appreciation of the historical and ideological origins of the conflict. Moreover, Nepal cannot merely adopt or import foreign models; it needs its own institutions tailored to the nation's priorities in light of its culture, history, and ideological orientations. For Nepal, this means a judicial structure that strikes a balance between accountability and independence, decidedly favoring the former. Most likely, it means creating new institutions like (1) a Judicial Complaints Commission to enforce accountability, rather than continuing to rely on a historically ineffective judicial council to do so, and (2) a new, freshly empowered constitutional court to interpret and apply constitutional protections and limitations, rather than continuing to rely on its supreme court to perform this function. Only by replacing the tried-andfailed, or at least tried-and-flawed, institutions against which the Maoists have rebelled for so many years can Nepal hope to forge some semblance of a consensus on the terms of its new constitution and chart a new future for the people of Nepal. 
